\title{
HUMANISTIČKO OBRAZOVANJE KAO POSLJEDNJA SVRHA LJUDSKOG OPSTANKA
}

\author{
Darija Rupčić \\ Filozofski fakultet, Sveučilište \\ Josipa Jurja Strossmayera u Osijeku, \\ Hrvatska \\ darijarupcic@gmail.com
}

Primljeno: 13. 7. 2015.

\begin{abstract}
Namjera je rada istaknuti važnost humanističkog ideala obrazovanja onako kako su ga shvaćale plejade velikih mislitelja i filozofa 18. $i$ 19. stoljeća. Cini se da temeljene vrijednosti $i$ san prosvjetiteljstva o sveobuhvatno samoobrazovanom i emancipiranom pojedincu u ovome našemu 'društvu znanja' polako odumiru. Svođenjem obrazovanja na izobrazbu ono postaje nešto strano i izvanjsko ljudskome duhu. U akademskim se zajednicama diljem Europe i svijeta osjeća snažan zaokret $i$ odricanje od temeljnih humanističkih ideja obrazovanja. Mnogo toga što se propagira i proklamira pod sintagmom 'društva znanja' čini se retorickom frazom. Brojne reforme obrazovanja vodile su i vode njegovoj ekonomizaciji i komodifikaciji, čime se temeljne humanističke vrijednosti i ideali izvrću i izdaju te time uloga kritičkog subjekta postaje gotovo nemogućom. Ako su osnovni zadaci sveučilišta traženje i predaja istine, onda oni nisu mogući ako za svoju posljednju svrhu nemaju odgoj i obrazovanje cjelokupnog čovjeka, koji su konstitutivni momenti ljudskosti i humaniteta. Koristeći se brojnim izvorima na spomenutu temu, a ponajprije iznesenim poimanjima ideje obrazovanja, očekivani doprinos rada ide u smjeru mogućnosti ponovnog otkrivanja i revaloriziranja humanističke i prosvjetiteljske ideje odgoja i obrazovanja.
\end{abstract}

Ključne riječi: obrazovanje(Bildung), znanje, ideja sveučilišta, humanistički odgoj i obrazovanje, neoliberalni kapitalizam

\section{Uvod}

Misliti o obrazovanju i s njime usko, gotovo nerazdruživo povezanom odgoju - u ovome našemu društvu znanja koje gotovo već pomalo 
olinjalim frazama deformira samo znanje, obrazovanje i njegov smisao - zahtijeva veliki oprez. Na inflaciju znanja ukazuje nam činjenica njegove komodifikacije i pretvaranja znanja u fragment i robu. Kada govorimo o znanju, tada naglašavamo kako se tu sve više radi o znanju kojemu nedostaje sinteza i sveobuhvatnost, znanju koje je podijeljeno na paketiće lako probavljivih činjenica koje nadomještaju kritičko mišljenje, tzv. »peri-deri znanje« (Jovanović, 2008, 47).

Znanje se često reducira na znanstveno znanje koje stoji nasuprot a često i antagonistički protiv narativnog znanja (Lyotard, 2005, 26-33). Takvo shvaćanje znanja pretvara obrazovanje (Bildung) u izobrazbu (Ausbildung). ${ }^{1}$ Cilj izobrazbe nije da nešto postanemo i budemo, nego da nešto možemo i imamo određene kompetencije (Liessmann, 2009, 9).

Obrazovanje koje se ravna prema antičkom i humanističkom modelu i konceptu predstavlja program cjelokupnog čovjekova (samo)formiranja, samoobrazovanja i skrbi za totalitet ljudskosti. Obrazovanje je to koje ide smjerom i načinom djelovanja po kojemu se čovjek određuje u smjeru ljubavi i čežnjom za stvaralaštvom, po kojemu čovjek postaje licem, osobom (Vuk-Pavlović, 1996, 119).

»Zato put, kojim hoće da ide čovjek kao lice, ne može da se prevali bez ljubavi, jer bez ljubavi prema duhovnome bitku, u kojem se usidruju vrednote, nema uzvisivanja opstanka, bez ljubavi prema duševnome bivanju, kojemu se obraća zov idealnih prohtjeva, nema oplemenjivanja bića, a bez ljubavi napokon k licima, prema kojima u svezi s kojima lice tek može da nađe i odredi sebe, nema ispunjenja života.« (Vuk-Pavlović, 1996, 120)

»Sintagma 'društvo znanja' nije novum niti isključuje industrijsko društvo« (Liessmnn, 2009, 8). Mnogobrojne reforme obrazovanja u svijetu, a kojih smo svjedoci i na našemu tlu, sve više vode komercijalizaciji, komodifikaciji, industrijalizaciji i ekonomizaciji znanja, čime

\footnotetext{
${ }^{1}$ Vrlo je važno barem ukratko (koliko je za potrebe ovoga rada i dovoljno) uputiti na značenje pojma Bildung kod prosvjetiteljskih mislitelja, a napose kod Kanta, Fichtea i Schellinga, a koji koristi i Liessmann. Ovaj pojam podrazumijeva, s jedne strane, kultivaciju samoga sebe temeljem vlastitih moći (samorazvoj, samoostvarenje), a s druge pak strane oblikovanje pojedinca kao ličnosti, građanina, čovjeka uopće (kao moralnog, umskog bića) pod utjecajem vanjskih faktora: odgoja, politike, kulture općenito. Stoga ovaj pojam često srećemo kao istoznačan pojmovima kultura (shvaćena kao proces, kao kultivacija), oblikovanje, formacija, izgradnja, razvoj. Bildung upućuje na formaciju čovječnosti u pojedinoj osobi, odnosno odgoj u najširem smislu riječi. Taj pojam također objedinjuje, uz odgoj (obrazovanje, naobrazbu, izobrazbu itd.), i druge elemente koji čine kulturu uopće, kao proces potpunog razvijanja ljudskih sposobnosti (Kwiek, 2006, 8, 9, 14, 26). Sva ova značenja treba imati na umu i pri razumijevanju ovoga teksta.
} 
se klasični, antički i humanistički koncept obrazovanja izvrće u svoje suprotnosti (Liessmann, 2009, 8).

Lyotard će u svojoj studiji o stanju znanja u najrazvijenijim industrijskim društvima, Postmoderno stanje, ustvrditi slijedeće:

»Jedina je uloga ovoga shematskog podsjetnika (ili samo kostura) preciziranje problematike u koju nastojimo smjestiti pitanje znanja u naprednim industrijskim društvima. Jer ne možemo znati u kakvom je stanju znanje, to jest s kojim se problemima njegov razvoj i prijenos danas susreću, ako ništa ne znamo o društvu u kojem se to događa.« (Lyotard, 2005, 19)

Razlozi takve promjene leže ponajprije u novonastalim ekonomsko-političkim promjenama paradigme u Europi i svijetu. U kurikularnim reformama diljem Europe i anglosaksonskim dijelovima svijeta naglasak se sve više stavlja na kompetencije, ishode i postignuća, od kojih su inicijativnost, poduzetnost i fleksibilnost najviše naglašene (Beder, Varney i Gosden, 2009, 80, 130-136; Hedges, 2011, 109-138; Lyotard, 2005, 64-67). Tako se svođenjem obrazovanja na izobrazbu zbiva nagli, radikalni zaokret u poimanju svrhe obrazovanja te izostavlja momenat humanističkoga u odgoju i obrazovanju.

Radi opsežnosti problematike upoznavanja s društvenim prilikama u kojima se mi danas nalazimo i pitanja samog znanja, kako znanstvenog tako i narativnog, ovdje nećemo previše zadirati u spomenutu tematiku. Ono što će zaokupljati našu pažnju na stranicama koje slijede bit će pitanje smisla i naravi samog obrazovanja te njegova transformacija od Humboldtova ideala obrazovanja kao posljednje svrhe čovjekova opstanka na Zemlji sve do obrazovanja kao potrošne robe lako probavljive i lako ispostavljive radi potreba tržišta, koje čovjeka pojedinca pretvara iz osobe, lica, u fleksibilnu i poslušnu radnu snagu. Čovjek tako postaje jedinkom bez osobnosti, uvijek spremnom učiti i staviti svoje snage na raspolaganje potrebama tržišta koje se mijenjaju enormnom brzinom. Time čovjek postaje karikaturom onoga što je nekada predstavljalo ideal obrazovnog pojedinca, onog autonomnog, emancipiranog, od stada odvojenog, jakog i samomislećeg pojedinca (Barber, 2003, 3-21, 34-37; Beder, Varney i Gosden, 2009, 67-71) te se reducira od osobe građanina na fleksibilnog poslušnika i konzumenta.

»Obrazovanje se sada promatra, u političkim krugovima diljem svijeta, kao 'proizvod za privatnu upotrebu', roba koja je na najefikasniji način proizvedena od poslovnog sektora i poduzetnika i koja se kupuje od strane roditelja koji žele dati svojoj djeci kompetitivne prednosti na tržištu budućih zanima- 
nja. Djeca se više ne promatraju kao budući građani čiji potencijali trebaju biti njegovani i razvijani, nego radije kao potrošači obrazovnih proizvoda, ljudski resursi za rast ekonomskog stroja i 'problem koji škole trebaju riješiti'.« (Beder, Varney, Gosden, 2009, 80; Engel, 2000, 33).

\section{Protuprosvjetiteljstvo - dekonstrukcija humanističkog ideala obrazovanja}

U takvoj konstelaciji i uvjetima koncept obrazovanja se radikalizirao, krenuvši drugim smjerom. Gledajući konfiguracije znanja danas u nepreglednoj industriji znanja i njegovoj reprodukciji, svi ti oblici znanja pojavljuju se zapravo kao njegova suprotnost i negacija, kao pojavni oblici neobrazovanosti (Liessmann, 2009, 8).

Ono što objedinjuje sve obrazovne reforme i reformatore svih smjerova njihova je netrpeljivost prema tradiciji antičkog i prosvjetiteljskog obrazovnog ideala i raskid s njom (Liessmann, 2009, 45; Lyotard, 2005, 39, 53-54). Sama pomisao da bi ljudi mogli pokazivati odlike slobodnih, emancipiranih, samomislećih pojedinaca, suvislog ali nesvrhovitog znanja koje bi bilo samom sebi svrha, znanja sadržajno usmjerenog prema tradicijama velikih kultura, znanja koje oblikuje karakter i cjelokupnog čovjeka podarujući mu slobodu nasuprot diktatima nametnutim izvana, za njih postaje odiozna i odbojna (Liessmann, 2009, 45; Hedges, 2011, 109, 115, 117).

Wilhelm von Humboldt u svojim je Djelima u pet svezaka objavio fragment »Teorija čovjekova obrazovanja« (»Theorie der Bildung des Menschen «), vjerojatno nastao 1793. ili 1794. godine. U pismu napisanom u studenome 1793. godine ustvrdio je kako kronično nedostaje išta što bi bilo barem začetak bilo kakve teorije obrazovanja (Bildung) (Humboldt, 1969, 57). ${ }^{2}$ »Krunu cjelokupnog intelektualnog napora među filozofima i znanstvenicima u Njemačkoj, krajem 18. i početkom 19. stoljeća, u pogledu modernog promišljanja ideje univerziteta - a s njim usko povezanom idejom Bildunga ili (samo)obrazovanja - »predstavljalo je osnivanje prvog slobodnog univerziteta u Berlinu 1809. godine« (Dimić, 2013, 248).

Ne ulazeći dublje u analizu razvoja sveučilišta, ono što je zaokupljalo pažnju i što je bio Humboldtov zadatak jest bilo baviti se idejom

${ }^{2} \mathrm{U}$ tekstu koristimo fragment iz Wilhelm von Humboldt $(1969,56-59)$ i prijevod u Humboldt, 1969, 234-240. 
obrazovanja i osnovati novo sveučilište u Berlinu, na poziv pruskog cara Friedricha Wilhelma III. Car je, nakon poraza kod Jene, bio odlučan provesti korijenite promjene te je barunu Heinrichu Friedrichu Karlu von Steinu dodijelio posebne ovlasti za oblikovanje i provedbu reformi. Osiguranje trajnog uspjeha reformi, a na temelju Steinova plana, trebala je biti reforma obrazovnog sustava. Stein je polagao velike nade u odgoj i obrazovanje koje je trebalo počivati na unutarnjoj prirodi čovjeka te u mladeži uspjeti pobuditi sve plemenite životne principe. Ono što je trebalo izbjegavati bilo je jednostrano obrazovanje. ${ }^{3}$

Stein je odlučio dodijeliti posao reforme obrazovnog sustava Wilhelmu von Humboldtu. Odlučio je to ne zbog toga što bi Humboldt imao neke specijalne službene kvalifikacije, nego zbog toga što je u njemu prepoznao posebnu osobnost koja je izražavala, uz sve ostale kvalitete, i posvećenost i brigu prema njemačkoj naciji. Program reformi koji je osmislio barun Stein uključivao je značajne mjere vezane uz oslobađenje seljaka-kmetova, stvaranje lokalne samouprave i nacionalne vojske, kao i reorganizaciju pruske vlade koja se raspala nakon poraza kod Jene. Krug ljudi okupljen oko baruna Steina, uključujući i vojne zapovjednike Gerharda von Schanhorsta, Neidhardta von Gneisenaua i Karla von Clausewitza, bio je duboko uvjeren u potrebu reforme obrazovanja. Smatrali su da je potrebno pružiti kvalitetno obrazovanje svim slojevima društva kako bi političke i vojne reforme uspjele (Anonymous, 2010).

Humboldt je već od ranije pokazivao simpatije i interes za ideju obrazovanja. Njegov prethodno spomenuti spis sasvim je jasno iskazao

\footnotetext{
${ }^{3}$ Bitka kod Jene vodila se 14. 10. 1806. godine između vojske Napoleona i Fridricha Wilhelma III od Prusije. Bitka je u punome svjetlu pokazala sve nedostatke pruskog feudalnog društva i vojske. Poraz kojega je doživjela Prusija i mjere koje su poduzeli vlastodršci, plemići i feudalci kako bi zemlju spasili od propasti vrijedni su sjećanja. To je otvorilo prostor reformistima kao što su bili Scharnhorst, Gneisenau i Clausewitz, koji su također sudjelovali u bitki, za provedbu nužnih reformi pruske vojske. One su zajedno s civilnim reformama pretvorile Prusiju u modernu državu, koja je samo šest godina kasnije postala jednom od predvodnica protunapoleonske koalicije i izbacivanja Francuza iz Njemačke. Strašni poraz kojega je Prusija doživjela bio je najučinkovitije upozorenje da je za obnovu nekadašnje snage Pruske države i spas od potpune propasti potrebno angažirati sve snage koja nacija posjeduje. Prusi su ispravno shvatili: ako žele da se država i nacija održe i obnove, onda se država ne smije smatrati ekskluzivnim pravom i brigom dinastije, nego brigom svakog čovjeka koji u njoj živi. Ovaj cilj mogao se je ostvariti tek nakon što se ljude izdigne iz stanja pasivne letargije koju je izazvalo stalno socijalno tlačenje i feudalni društveni odnosi. Podanike kraljevstva trebalo je preobraziti u aktivne sudionike u javnim poslovima, u građane države.
} 
njegove poglede na posljednju svrhu obrazovanja i njezinu vezu s čovjekovom biti (Dimić, 2013, 249; Spranger, 1910, 32-33; Humboldt, 1969, 58). Humboltova reforma pruskog školskog sustava temeljila se u njegovoj odlučnosti da stvori građanina koji je trebao biti samomisleći pojedinac. Za Humboldta je obrazovanje:

»Posljednji zadatak našeg postojanja, pojmu čovještva u našoj osobi, priskrbiti što je moguće više smisla, tijekom vremena našega života i nakon njega, tragovima životne djelatnosti što je ostavljamo za sobom. To se može ostvariti samo povezujući se sa svijetom, sve do najopćenitijeg, najživljeg i najslobodnijeg uzajamnog utjecaja.« (Humboldt, 1969, 58)

Dakle, Humboldt naglašava upravo taj neizbrisivi doprinos pojedinca pojmu čovječanstva i čovječnosti u nama samima te tijesnu vezu pojedinca sa svijetom koji ga okružuje, kao i neosporan trag koji ostavljaju veliki ljudi. Za njega, obrazovanjem je čovjek trebao zahvatiti što je moguće više svijeta $i$ što tijesnije se s njime povezati. Ono što mi zahtijevamo od nacije i čitavog ljudskog roda, isticao je, činjenica je da obrazovanje, mudrost i vrlina, što snažnije i univerzalnije propagirane, opstanu te trajno i neizbrisivo stanu pod njihovo okrilje (Humboldt, 1969, 59).

Taj zahtjev, kako ga ističe Humboldt, ne treba stati na tome. Čovjek treba ostaviti neizbrisiv trag i vidljiv otisak svoje veličine i vrijednosti na sve ono što oblikuje i čini. Bez tog uzdizanja i obrazovanja, bez procesa samoobrazovanja, koji je put pojedinca ka samome sebi, ljudski život ne bi vrijedio ništa više od života biljke ili cvijeta. Tada čovjek svojim vlastitim djelovanjem i angažmanom doprinosi razvitku humanosti, a spoznavanje svijeta, slobodna djelatnost i komunikacija čine bitne dimenzije ljudskog opstanka (Humboldt, 1969, 58-59).

Jezgra Humboldtove ideje i teorije obrazovanja ne leži u odvraćanju od svijeta, zatvaranju u »kule bjelokosne« i neke elitističke obrazovne i verbalne enklave, nego u njegovu zahvaćanju, približavanju svijetu, stalnoj interakciji kroz djelatnost. Obrazovanje shvaćeno na taj način predstavlja posrednički posao između individualnih razvojnih mogućnosti i općenitih zahtjeva, uvriježenosti objektivnog duha. Iz ove perspektive, obrazovanje opisuje program postajanja čovjekom kao duhovni rad na sebi i na svijetu. Tako se ideja znanosti kao duhovnog prožimanja svijeta spoznajom ne može odvojiti od ideje obrazovanja.

Za Hegela, primjerice, obrazovanje nije ništa duhu nametnuto niti izvanjsko, nego je ono medij ozbiljenja duha po kojem se duh ostva- 
ruje. Duh je ono što se obrazuje; samo ono što se obrazuje može se nazvati duhom.

»Ono po čemu dakle individuum ovdje važi i po čemu je zbiljski jest obrazovanost [...]. Ta se individualnost oblikuje u ono što je ona po sebi, i tek time ona jest po sebi i ima zbiljski opstanak; koliko ima obrazovanosti, toliko zbiljnosti i moći.« (Hegel, 2000, 317)

Humboldt se zalagao za opće, a ne usko specijalizirano obrazovanje te je smatrao kako škole trebaju biti za sve. Ponovno je revidirao onu staru antičku ideju lutanja i znanstvenog tumaranja, istraživanja i izgradnje vlastitog methodosa kao nužnog puta u znanost i filozofiju, ističući tako tri temeljna principa suvremenog sveučilišta koji se sve više danas gube. To su bili: jedinstvo nastave $i$ istraživanja, jedinstvo znanosti i akademska sloboda nastavnika i studenata (Dimić, 2013, 85, 253, 257).

Međutim, iako je ideja sveučilišta kako su je zamislili Kant, Fichte, Schelling, Nietzsche i Humboldt ostala i danas možda neka sve daljnja čežnja, ono što će se odvijati nimalo nije svjedočilo ovome u prilog. Naime, Humboldt se već 1810. godine vraća u diplomaciju i sve se više udaljava od nastave, a proces odvajanja pojedinačnih znanosti od nastave i filozofije više se nije mogao zaustaviti. Dimić ističe kako se obrazovanje u smislu Bildunga, samoobrazovanja i samorazvoja, žrtvovalo i vrlo brzo podredio "potrebama države za proizvodnjom kompetentnih kadrova za normalno funkcioniranje administracije, tj. potrebe za rastom industrijske proizvodnje« (Dimić, 2013, 253). Tako je ideja traženja i znanstvenog tumaranja, izgrađivanja vlastitog methodosa, bila prodana državi u ime realizacije velikih nacionalnih ideja i planova.

Neuspjeh humanističkog zahtjeva za obrazovanjem konstatirao je već mladi Friedrich Nietzsche kada je, tek što je bio imenovan profesorom klasičnih jezika na Sveučilištu u Baselu 1872. godine, u obliku javnih predavanja promišljao na temu budućnosti obrazovnih ustanova (Nietzsche, 1991, 247-329). Nietzsche je konstatirao beskrajnu razliku između preuzetnosti kojima se humanistička škola više ili manje dragovoljno izlagala i njezine odveć bijedne realnosti.

»... gimnazija, po svojoj izvornoj formaciji ne odgaja za obrazovanje, nego samo za učenost i dalje, da odnedavno mijenja smjer, kao da čak više neće odgajati ni za učenost, nego samo za žurnalistiku.« (Nietzsche, 1991, 273) 
Zanimljivo je kako je već te davne 1872. godine Nietzsche tvrdio da obrazovnim ustanovama vladaju dvije prividno suprotstavljene, u svojim djelovanjima jednako pogubne i u rezultatima stopljene tendencije ili struje. Jedna je težnja ka što je moguće većem proširenju obrazovanja, a druga je težnja k umanjivanju i oslabljivanju samog obrazovanja (Nietzsche, 1991, 266).

Proširivanje obrazovanja bila je omiljena nacionalno-ekonomijska dogma koja je tada dominirala. Što je moguće više spoznaje i obrazovanja, produkcija znanja koje bi bilo korisno za stjecanje što je moguće više novca. Tako bi trebalo obrazovati što više ljudi koji bi bili sposobni zaraditi, tzv. »kurentne ljude« (Nietzsche, 1991, 266). Toj je tendenciji strano i omraženo svako obrazovanje koje usamljuje, koje postavlja ciljeve iznad novca i probitka, koji troši mnogo vremena, a te se obrazovne tendencije etiketira kao viši egoizam, nećudoredni obrazovni epikureizam, te se traži suprotno, brzo obrazovanje, da bi se hitro i brzo moglo postići zaradu. Nasuprot toj tendenciji stoji stremljenje ka smanjenju obrazovanja, ističe Nietzsche, koje se nastoji oslabiti, raspršiti na usko specijalizirano znanje, fragmentirati ga i rascjepkati. Od društveno svjesnog pojedinca stvarao se ekskluzivni specijalist i stručnjak. Na taj se način gubilo ono sveobuhvatno, orijentacijsko znanje koje se svodilo na žurnalistiku. Tako je »novinar, sluga trenutka, stupio na mjesto velikog genija, vođe za sva vremena, izbavitelja od trenutka« (Nietzsche, 1991, 269).

Za Nietzschea je postojala samo jedna istinska opreka - ustanove obrazovanja - o kojima je on tako gorljivo pričao i pozivao na njihovo očuvanje, nasuprot ustanovama životne nužde, u koju spadaju sve tada postojeće. Zapanjujuće je kako se danas sve više događa degradacija sveučilišta i klasičnog antičkog obrazovanja na ustanove životne nužde koje služe potrebama tržišta.

Riječ škola, koja etimološki potječe od latinskog shola te se može svesti na grčku riječ shole, prvotno je značila zaustavljenost u radu, a sada je

»... prestala biti mjestom dokolice, usredotočenosti, kontemplacije [...] [Njome] dominiraju projekti i praksa, iskustva i umreženja, ekskurzije i izleti.« (Liessmann, 2009, 53)

Škola je postala mjestom životne nužde. Vremena za onu usamljenost i razmišljanje u tišini, na koje nas je Nietzsche pozivao, više nema (Liessmann, 2009, 53). 
Nietzsche se jasno opredijelio protiv općeg obrazovanja za široke mase, koje nikako ne može biti naš cilj, a za klasično obrazovanje onih rijetkih ljudi, istinski obrazovanih za trajna i velika djela. Tako je obrazovanje za njega vezano uz proces individuacije i nikako nije prikladno za šire mase i poopćavanje, što je za njega zapravo predstavljalo barbarstvo (Nietzsche, 1991, 277). Obrazovanje je usamljeni proces i oni koji se žele obrazovati moraju poći na herojski životni hod putem osame (Nietzsche, 2003, 5). U svojem je djelu Schopenhauer kao odgajatelj Nietzsche isticao kako je tajna svakog obrazovanja oslobođenje, a pravi, istinski odgajatelj oslobađa, uklanja korov, otpad, gamad i unosi svjetlost i toplinu u svoga odgajanika (Nietzsche, 2003, 7).

U Nietzscheovo je vrijeme obrazovno građanstvo bilo novi sloj koji se formirao u sjeni tadašnje ekonomski moćne buržoazije i predstavnika poslovnog i trgovačkog svijeta, koji sami nisu priznavali ove ideale antičkog građanskog i humanističkog pojma obrazovanja. Naime, kompenzirajući nedostatak ekonomske imućnosti i političke moći posjedovanjem obrazovanja i silom raspolaganja obrazovnim dobrima, što je Nietzsche jasno uviđao i britko i cinično ismijavao, taj je sloj počeo vjerovati i sebe doživljavati kao nekoga tko je bolji i uzvišeniji nad ostalima te se pretvarati u svoju karikaturu.

Nedvojbeno je, kako ističe i Liessmann, da je nešto od te moderne ideje sveučilišta danas i ostalo u našem suvremenom društvu. Uzbuđenje i eros zbog rezultata znanstvenih istraživanja još se hrane samospoznajom, međutim ono što je sve više vidljivo činjenica je rastakanja i destrukcije ideje obrazovanja, sveučilišta i slobode akademske zajednice te općenito rastakanje i iščezavanje sloja obrazovanih građana kao etabliranog samosvojnog staleža (Liessmann, 2009, 57).

S nivelirajućim omasovljenjem znanja polako nestaje tzv. obrazovni sloj ljudi koji je na temelju kontinuiranog školovanja i rada na sebi razvijao disciplinu mišljenja i osjećanja, po kojoj je mogao biti odjekom duhovnog stvaralaštva svoga vremena. Demontažom i dekonstrukcijom humanističkih gimnazija i humboldtovskog sveučilišta, obrazovanje sada postaje nešto izvanjsko i strano duhu. Natjecateljski orijentirano polazište znanje tretira kao sredstvo korisnosti i primjenjivosti. Pravo je znanje pretpostavka za čovjekovu mogućnost, pretpostavka da pojmi samog sebe kao moralno biće. Nijedno društvo stoga nije o znanju govorilo tako odbojno kao društvo znanja jer mu nije stalo ni do obrazovanja niti do istine (Liessmann, 2009, 61-62). 


\section{Klima poluobrazovanosti}

Kolizija modernog medijskog i tehnološkog društva s idealima i normama obrazovanog građanstva proizvela je pojam poluobrazovanja uz pomoć kojega je Theodor W. Adorno, napisavši 1959. godine Teoriju poluobrazovanosti, analizirao odnose i stanje u obrazovanju poratnoga društva. Ustvrdivši da, ukoliko humanističko obrazovanje postane ciljem ljudima kojima za to nedostaju preduvjeti, prvenstveno dokolica, utoliko mora zavladati poluobrazovanost (Adorno, 1959, 99).

U uvjetima kulturne industrije obrazovanje postaje specijaliziranim poluobrazovanjem kao sadašnji pojavni oblik »otuđenoga duha « (Adorno, 1959, 93; Horkheimer i Adorno, 1989, 154, 160-162). Sva se nastojanja humanističkih ideala onemogućavaju i ruše komodifikacijom i opredmećivanjem obrazovanja. Obrazovanje, kao živi obračun duha sa samim sobom i svijetom, transferira se u mješavinu kulturnih dobara koja se mogu steći i konzumirati, ali se više ne daju prilagoditi:

»U klimi poluobrazovanja preživljavaju robno postvareni sadržaji obrazovanja na račun u njemu sadržane istine i njegova živog odnosa spram živih subjekata.« (Adorno, 1959, 103)

Redukcija obrazovnog kanona i sužavanje kurikuluma označavalo je postvarenje obrazovanja i njegovu degradaciju i svođenje na robu. Tako se obrazovni kanon reducirao na nekoliko krilatica i fraza koje se didaktički razrađuju i brzo usvajaju, a da se pritom ne razumije nikakav suodnos. Za Adorna, to je označavalo naličje obrazovanja, poluobrazovanje:

»Napola razumljeno i napola iskušano nije predstupanj obrazovanja, nego njegov smrtni neprijatelj.« (Adorno, 1959, 111)

Poluobrazovanje, dakle, ostaje tako nerazumijevanje jer se ipak vezuje uz kategorije obrazovanja, ali ga se više ne može shvatiti. Elementi obrazovanja još su prisutni, ali postali su nešto strano i izvanjsko.

"Stoga je poluobrazovanost razdražljiva i ljutita; znati sve o svemu ujedno znači i htjeti pametovati.« (Adorno, 1959, 116)

Nedvojbeno je da su tragovi poluobrazovanja, onako kako ih je Adorno dijagnosticirao, još uvijek svuda vidljivi (Liessmann, 2009, 59), primjerice u sužavanju kurikuluma u reformama obrazovnih sustava diljem svijeta. 
»'Neobrazovanost' [...] znači da je ideja obrazovanja u svakom pogledu prestala ispunjavati normativnu ili regulativnu funkciju. Ona je jednostavno nestala. Otuđeni duh koji se kod Adorna još provlačio u obrazovnim dobrima [...] pretvorio se u aklamiranu nestašicu duha.« (Liessmann, 2009, 60)

Neobrazovanost u našem suvremenom smislu ne znači odsutnost znanja ili čak i glupost (Liessmann, 2009, 60). Odvraćanje od ideje obrazovanja najjasnije se pokazuje tamo gdje se to možda ponajmanje pretpostavlja: u središtima samog obrazovanja, u obrazovnim institucijama. Primjerice, u već odavno pokrenutom preusmjeravanju obrazovnih ciljeva na sposobnosti i kompetencije (vještine ili skills) (Liessmann, 2009 , 61) riječima kao što su sposobnost za timski rad, fleksibilnost i komunikacijske vještine, što postaje snažnim indikatorom za odvraćanje od ciljeva obrazovanja ili onoga što se naziva Bildung. Radi se o »suspendiranju one individualnosti koja je nekoć bila adresat $\mathrm{i}$ akter obrazovanja« (Liessmann, 2009, 61). Liessmann će ustvrditi:

»Neobrazovanost danas nije stoga nikakav intelektualni deficit, nije nedostatak informiranosti, nije defekt kognitivne kompetencije (premda će sve to i nadalje postojati), nego je odricanje od htijenja da se nešto uopće razumije.« (Liessmann, 2009, 61)

Obrazovanje je način življenja, kralježnica mu je disciplina kao umijeće mišljenja, a prostor sređeno znanje (Jaspers, 1998, 121). Gdje god se danas govori o znanju, radi se o nečemu drukčijem od razumijevanja.

»Posjedovati nekakvo znanje ujedno znači i svjedočiti o njemu, biti svjedokom njegovog nastajanja i razvijanja. Onaj koji zna, znalac znanja, ujedno je i svjedok znanja [...] Znanje nije nešto što može biti neutralno, što se negdje može 'skladištiti' i što može nastati neovisno od nekog nositelja, već ono uvijek ima svoga tvorca, tj. onoga tko se u njemu osvjedočio [...] Spoznavati, učiti, zapravo znači tražiti nešto opće iznad onog partikularnog [...] koje se tiče naših interesa, hirova, samovolje, strasti, sklonosti itd., zaboraviti, staviti na stranu, kako bi se kroz intersubjektivno posredovanje došlo do općeg.« (Dimić, 2013, 84)

Sve to dodatno potencira i oslikava mukotrpnost i usamljenost tog herojskog pothvata i puta spoznavanja i samoobrazovanja, na koji je još Nietzsche upozoravao.

Time se stvara osnovni temelj za razvoj ideje o obrazovanju.

»... pravog znanja nema bez osobne avanture istraživanja, tumaranja i lutanja. Put obrazovanja zapravo je put samoobrazovanja. Ako želimo izvesti sebe iz postojeće krize znanja i ideje univerziteta, ne smijemo se više zadovoljavati 
time da budemo 'skladištari' znanja, već moramo ponovno postati njegovi svjedoci. Put izlaska iz postojeće krize upravo bi mogao voditi u pravcu ponovne afirmacije znanstvenog tumaranja.« (Dimić, 2013, 85)

\section{Revizija ideje sveučilišta - sveučilišta kao posljednji javni prostor}

Moderna ideja sveučilišta nastala je i razvijala se pod neposrednim djelovanjem i okriljem prosvjetiteljskih i romantičarskih ideja. Ono što je važno za samu ideju i njezino očuvanje naš je osobni stav prema znanju, obrazovanju, nastavi i samoj ideji sveučilišta, što postaje i od izuzetne konstitutivne važnosti. Odnos moderne ideje sveučilišta prema njezinoj epohi ne možemo razriješiti na općoj razini, već se trebamo okrenuti svakom autoru ponaosob, kako smo već jednim dijelom nastojali prikazati kroz osnovne misli vezane uz samu ideju obrazovanja, njezinu bit i smisao, te s njom u vezi i ideju sveučilišta. Međutim, toliko opsežna i sadržajno bogata tematika i tekstovi toga razdoblja iz kojih jasno iščitavamo opći epohalni idejni kontekst ali i duboke osobne linije filozofiranja o samoj ideji sveučilišta i obrazovanja uvelike nadilaze opseg ovog našeg promišljanja pa ćemo navesti samo neke opće idejne koncepte kako bismo rasvijetlili što je moderno sveučilište, nastalo na zasadama Humboldtove ideje sveučilišta, a prije njega i Kantove, predstavljalo nekada, a što bi od toga danas moglo nanovo biti »osvojeno« ili »spašeno« od destrukcije i propasti. Kako smo, nažalost, svjedoci žrtvovanja i podređivanja ideje sveučilišta i obrazovanja diktatima tržišta, važno je naglasiti što je to što bismo trebali sačuvati i zašto. U ime čega i zbog čega.

Kada postavljamo pitanje smisla odgoja i obrazovanja, ne možemo ne spomenuti i Jaspersa, koji je u svojemu djelu Duhovna situacija vremena jasno isticao da čovjek tek po odgoju i obrazovanju, vlastitom aktivnošću i angažmanom u svijetu, postaje čovjekom i približava se sudjelovanju u znanju o cjelini. On ulazi u svijet, i što je svijet ispunjeniji i jasniji, to čovjek biva više svoj (Jaspers, 1998, 106). Do istine se ne može nikako doći njezinim pukim preuzimanjem, nju treba zavrijediti i osvojiti ju vlastitim autentičnim činjenjem, vlastitim misaono-istraživačkim radom. To činjenje treba biti slobodno od pritisaka autoriteta svih vrsta, jedino pod zakonodavstvom i diktatom uma, kako je i Kant naglašavao. 
Fichte, slično tome, naglašava da samo vlastitim snagama čovjek samoga sebe može odgojiti i kultivirati.

»Nitko ne biva kultiviran, već svatko treba samog sebe kultivirati. Svako ponašanje koje je samo pasivno, upravo je suprotnost kulturi; obrazovanje se događa pomoću samodjelatnosti i smjera na samodjelatnost.« (Fichte, 2006, 90)

Fichte je smatrao kako tromost, lijenost, nepokretnost i inercija, koja samu sebe navikom reproducira do u beskonačnost i tako postaje posvemašnja nemoć spram dobra, zapravo predstavlja pravo, istinsko, urođeno radikalno zlo što leži u samoj srži ljudske prirode (Fichte, 1995, 195-202). Isticao je kako se nitko ne može uživjeti u dušu drugoga, već mora računati na njegovu samostalnost i posebnost. U odgoju, Fichte je naglašavao kako mi drugima ne možemo dati naše misli i krute jasne smjernice, nego samo naputke i eventualno pokazati put. Obrazovanje za njega, od najranije čovjekove mladosti, jedini je put filozofije, a to je put zbiljske slobode i samoostvarenja, put samostalnosti (Fichte, 1956, 258-260; Horkheimer i Adorno, 1989, 258). Na tom putu čovjek ne može očekivati poticaje izvana, nego iz samoga sebe, ako želi doći do samosvjesti i velikih misli. Ako pojedinca učinimo instrumentom za druge, on postaje trom, promašuje svoju navlastitu prirodu ali i svrhu odgoja i obrazovanja.

Prosvjetiteljski je ideal obrazovanja, koji se institucionalizirao u školskim ustanovama na raznim razinama, predstavljao snažnu reakciju na neizbježnu specijalizaciju znanja koja je u ono vrijeme uzela maha i vodila je funkcionalnosti znanja i obrazovanja, fragmentaciji, inovacijama u znanosti i tehnici te institucionalizaciji principa napretka (Dimić, 2013, 188). Prosvjetiteljska ideja obrazovanja podrazumijevala je prije svega novu ideju čovjeka, novu ideju subjekta kao autonomnog nositelja i legitimnog aktera društvene zajednice. Čovjek se sada shvaća kao »opća norma jednog nad-staleškog, nad-konfesionalnog, nadhistorijskog i nad-nacionalnog bića (Dimić, 2013, 188), a obrazovanje u smislu Bildunga značilo je njegovu legitimaciju i mjesto u društvu.

Liessmann smatra kako je vrijeme »humanističke poluobrazovanosti«, vrijeme neuspjelog pokušaja građanskoga društva 19. stoljeća da dosegne ideal humanističke obrazovanosti, onoga što su Grci zvali $p a-$ ideia (spoznati svijet, prilagoditi svijet, raspolagati prirodom radi samospoznaje i slobode), vrijeme koje je nepovratno prošlo. Nama preostaje samo Unbildung. Unbildung dakako nije neobrazovanost u smislu neznanja. Unbildung je carstvo nužnosti, carstvo praktičnog, nerefleksiv- 
nog, carstvo »nosi-i-baci«, »peri-deri«, »rješavamo-to-u-hodu« znanja (Jovanović, 2008, 47).

Slično Liessmannovu »ludilu rangiranja« (Liessmann, 2009, 71), Illich je kritizirao mit o mjerenju vrijednosti, činjenicu uvođenja kvantifikacije i komodifikacije vrijednosti u škole i obrazovanje u cjelini, te je isticao:

»Jednom kada ljudi prihvate ideju kako školovanjem vrijednosti mogu biti proizvedene i mjerljive, oni teže prihvatiti sve vrste rangiranja [...] U naškolovanom svijetu put ka sreći popločan je konzumerističkim indeksom.« (Illich, 1970, 19)

Korporativno proizvedeni edukativni materijali - ili kako ih Illich govoreći o mitu pakiranja vrijednosti slikovito naziva "paketići znanja« (Illich, 1970, 19) - nisu novost u školama. Škole su bile korištene od strane korporacija kako bi promovirale konzumerizam, još od davnih 1920-ih. Međutim, danas je to poprimilo široke razmjere.

»Korporacije, nastojeći zadobiti i poboljšati javni ugled, povećavaju proizvodnju vidljivosti i uspostavljaju konzumeristički životni stil, u velikom su slučaju odgovorne za američku obrazovnu krizu.« (Lapp, 1994, 14)

Škole u SAD, primjerice, primaju 2,5 milijardi dolara godišnje od komercijalne veze s korporacijama (Beder, 2009; Molnar, 2005, 19).

"Zamisli milijune studenata kako razgovaraju o tvojim proizvodima u razredu. Zamisli njihove učitelje kako predstavljaju stajalište tvoje korporacije." (Beder, 2009)

Korporacije prodaju svoje proizvode djeci, stvarajući lojalnost brendovima, i na taj način popravljaju svoj ugled. Tijekom tih transformacija paradigme obrazovanja i promjena u metodama, došlo je i do promjene uloge autoriteta učitelja. Nekoć autonomni subjekti obrazovnog procesa, hvaljeni zbog svojih metoda usmjerenih na dijete koje je bilo u samoj jezgri nastave i obrazovanja, tijekom osamdesetih godina dvadesetoga stoljeća postaju distributerima znanja koji nude male paketiće i fragmente znanja suženog na određene sekvence, bez imalo autonomije i slobode u odlučivanju. Učitelji postaju kontrolorima, koji kažnjavaju učenike, njihovu kreativnost i spontanost, eliminirajući humor, smijeh i zabavu, formalizirajući interakciju među učenicima, provodeći stalne drilove i testiranja, ostavljajući i učenike i učitelje bez životne radosti i entuzijazma za svoj posao (Beder, Varney i Godsen, 
2009, 136). Lančani odgovori u malim jedinicama i paketićima, kako ih se u većini američkih škola promovira, mogu ohrabriti proizvodnju timskih igrača kakve poslodavci žele, ali mogu i obeshrabriti predvodnike, vođe koji misle drugačije, kritično, disidente i one koji mogu postavljati progresivna i neugodna pitanja, ljude koji su tako potrebni i nužni za razvoj društva i mudrosti (Beder, Varney i Godsen, 2009, 137).

Nameće se pitanje gdje su tijekom ove transformacije i komodifikacije obrazovanja u zemljama engleskog govornog područja u svemu tome bili sveučilišni profesori, nastavnici, školski odbori, roditelji? Bilo je nešto diskusija, sporadične borbe protiv komercijalizacije škola, diskusija koje su se vodile na razini školskih odbora. Snažan kulturološki faktor odigrao je ključnu ulogu u obilježavanju škola i otvaranju njihovih vrata korporativizmu, kako ističe Naomi Klein. Mnogi su roditelji i odrasli uključeni u odgoj i obrazovanje djece i mladih bili bespomoćni i prepustili se struji, smatrajući kako je otpor ionako uzaludan jer su djeca sa svih strana okružena reklamama pa se zaštita obrazovnog prostora od komercijalizacije smatrala uzaludnom u odnosu na koristi koje bi škole od reklama mogle dobiti. Mnogi su smatrali da jedna ili dvije reklame neće naškoditi (Klein, 2002, 83).

Moralni nihilizam kojega su prigrlila elitna sveučilišta diljem svijeta, zaprepastio bi mnoge. Radikalizirano zlo o kojemu su govorili Fichte i Adorno postaje mogućim jedino ako u njegovu nastanku surađuje i bojažljivo, zastrašeno i zbunjeno građanstvo i akademska zajednica, i to uz pomoć sustava promidžbe i masovnih medija koji nude spektakl i površnu zabavu. Suviše je studenata i profesora smušeno i podijeljeno, usko specijalizirano, atomizirano i plaho (Hedges, 2011, 113). Prevladava razbijenost i nedostatak svake kohezije.

»Obrazovanje, barem sustav obrazovanja u kojemu se studenti potiču da propituju vladajuće postavke i uče samokritičnosti, žrtvovano je u faustijanskoj pogodbi.« (Hedges, 2011, 115)

Kultura konkurentne učinkovitosti, utonulost u elektroniku, obavljanje svakog posla velikom brzinom, povezivanje, umrežavanje po kriteriju karijere kao načina života, uz prestiž i novac, pokrenuli su povezivanje takozvanih najboljih i najbistrijih sa zdravorazumskim obvezama spram društva, očuvanja okoliša i demokratskih ideala. Negdje na putu u slobodno tržište, elitna su sveučilišta zaboravila kako se učenje ne svodi na rukovanje, doturanje rezimea $i$ iskorištavanja pogodnosti 
na tržištu. Obrazovanje se ne može svesti na obuku i uspjeh definiran novcem (Liessmann, 2009, 62, 76-85; Hedges, 2011, 117).

Čak i u anemičnom i marginaliziranom svijetu studija humanističkih znanosti, osobito u SAD, ono što se poučava postoji u moralnoj praznini i izvlači iz nje (Hedges, 2011, 125). Upravo se, s nasrtajem na humanističke i društvene znanosti i njihovom sustavnom marginalizacijom, dogodio i krah i bankrot našeg gospodarskog i političkog sustava. To je zanemarivanje omogućilo elitama da obrazovanje i društvo ustroje oko već sročenih odgovora na već predodređena pitanja. Studenti se poučavaju određenim sklopovima mišljenja kako bi se iz njih dobili dirigirani odgovori, kako bi se očuvale i održale postojeće gospodarsko-političke strukture.

»Ljudi ne postaju ono što bi po prirodi trebali postati, već postaju ono u što ih društvo pretvori. Plemeniti osjećaji, visoka stremljenja duha, ovako kako danas stoje stvari suzuju se, trgaju, nasilno izvitoperuju i obogaljuju kako bi ih se uklopilo u naš odnos sa svijetom, što podsjeća na način na koji prosjaci osakaćuju i unakazuju svoju djecu kako bi ih što bolje prilagodili njihovu budućem životnom položaju.« (Hazlitt, 1902, 155)

Međutim, ovo još ne objašnjava kako to da se komercijalizacija dogodila i na sveučilištima. Profesori su šutke i pasivno promatrali kako korporacije gaze njihova načela slobode istraživanja i rasprave, izricanja i pronalaženja istine u javnim procesima, kako je isticao Kant i mnoštvo drugih filozofa koji su začetnici ideje univerziteta kao prostora slobode i kritičkog mišljenja, svega onoga što sačinjava akademski život. Zabrinutost raste $s$ činjenicom da se ovakav uzorak preslikava i na naše školstvo i polako uvlači na naša sveučilišta. Jesu li dio objašnjenja za osobni neangažman i nedostatak mobilizacije sveučilišta konformizam, strah, kukavičluk, lijenost ili sebični interesi? Je li tome doprinijela činjenica da su profesori i studenti na društvenim i humanističkim usmjerenjima diljem SAD ostajali indiferentni prema korjenitim promjenama u kulturi i u prioritetima sveučilišta, pita se i Klein (Klein, 2002, 84; Donoghue, 2008, 91). Desetljećima se u SAD sustavno uništavalo i zapuštalo obrazovanje s područja društvenih i humanističkih znanosti. Sve više raste sumnjičavost prema intelektualnoj znatiželji i spremnosti na propitkivanje i kritičko mišljenje, a jedini kriterij i mjerilo je korisnost (Hedges, 2011, 133). Možda je to ono što se odvija i kod nas?

Bijeg iz humanističkih znanosti predstavljao je bijeg od savjesti. Stvara se elitna klasa stručnjaka koji rijetko gledaju dalje i izvan okvira 
svojih znanstvenih disciplina kako bi ono čime se bave stavili u neki širi, društveni kontekst. Držeći se podalje od moralnih i društvenih pitanja što ih potiču i postavljaju humanističke znanosti, neki su se stavili u službu korporativnim strukturama koje su sustavno uništavale kulturu u njihovim sredinama.

Luis Althusser ističe kako škola, uz obitelj i crkvu nekada, provodi sustavno usađivanje ideologije vladajuće klase, a da se ona više ne preispituje. To se događa kroz usvajanje različitih znanja i vještina potrebnih za kasniju reprodukciju proizvodnih odnosa, uz selekciju tijekom procesa školovanja (Althusser, 1986, 36, 40, 42-43). Školski ideološki aparat, kako ga Althusser naziva, kao niti jedan do sada ima ogroman utjecaj i mnogo vremena na raspolaganju tijekom kojega masovno provodi ideje klase na vlasti, pri čemu mnogi učitelji i nesvjesno postaju produženom rukom takvog sustava.

»Ispričavam se onim učiteljima koji, u užasnim uvjetima, pokušavaju okrenuti ono malo oružja, koje mogu naći u historiji i znanju koje 'poučavaju', protiv ideologije, sustava i praksi u kojima su zarobljeni. Oni su svojevrsni heroji. Ali oni su rijetki i toliko njih (većina) i ne posumnja u 'rad' koji ih sustav (koji je veći od njih i mrvi ih) tjera da čine, ili još gore, ili da ulože svoje srce i oštroumnost u izvođenje s najvišom savjesnošću (čuvene nove metode!). Oni tako malo sumnjaju da njihova vlastita predanost doprinosi održavanju i hranjenju ove ideološke predodžbe škole, koja čini školu danas 'prirodnom', neophodno korisnom pa čak i blagotvornom za naše suvremenike kao što je Crkva bila 'prirodna', nezamjenjiva i plemenita za naše pretke prije par stoljeća.« (Althusser, 1986, 46)

\section{Umjesto zaključka}

Možemo zajedno s Naomi Klein ustvrditi kako je ipak bilo dosta onih koji su podigli svoj glas i izražavali nezadovoljstvo, no tijekom tih nekoliko ključnih godina korporacijske invazije na sveučilišta bili su zaokupljeni nekim drugim temama i diskusijama o spolu, diskriminaciji, rasnim aspektima. Bili su zaokupljeni razgovorima o argumentima za i protiv običajnih prava i potrebi strože politike spram seksualnog uznemiravanja u kampusu. I tako su, boreći se oko ženskih studija i zaokupljeni nekom posljednjom revolucionarnom knjigom ili teorijom, bili previše zaokupljeni da bi vidjeli da se njihova osnovna prava i principi slobodnog akademskog diskursa, zbog nečije brze zarade, rasprodaju i ograničavaju (Klein, 2002, 84). Ono što je bilo izgubljeno kroz 
komodifikaciju, osim navedenoga, gubitak je i same ideje nemarkiranog, nebrendiranog prostora (Klein, 2002, 84), škole i sveučilišta kao posljednjeg bastiona $\mathrm{i}$

»... kulturološki najopipljivije utjelovljenje javnog prostora i kolektivne odgovornosti [...] Oni su jedino preostalo mjesto gdje mladi ljudi mogu vidjeti autentičan pravi javni život. I ma kako nedostatno štitili ove institucije u prošlosti, u ovoj točki naše povijesti argument protiv transformacije obrazovanja u vježbe širenja marke, gotovo je isti kao i onaj za nacionalne parkove i prirodne rezervate: ova kvazi-sveta mjesta podsjećaju nas da je nemarkirani prostor još uvijek moguć.«(Klein, 2002, 84-85)

Sveučilišta, kao javni prostor i bastion obrane kritičkog mišljenja i slobode akademskog izražavanja, ostaju i trebaju ostati onaj prostor javnosti i publiciteta, »kao refleksivnim stanjem našega duha kojim se razmjenjuju perspektive gledanja aktera « (Kant, 2000, 9), prostor kroz koji se jedino može doći do istine i ponovno je osvojiti sučeljavanjem različitih perspektiva. Na taj način, usuđujemo se ustvrditi, sveučilišta postaju mjestom istinskoga razvoja slobode i duha, čovjeka pojedinca, koja kroz pluralitet i sučeljavanje s drugima i drugačijima, u $\gg j$ avnoj upotrebi uma « (Kant, 2000, 8), postaju obrana od sebičnosti, lijenosti, konformizma, a time i mjestom rađanja skrbi za druge. Zaključit ćemo stoga s Kantom:

»Jedina je obrana od egoizma i njemu se možemo suprotstaviti pluralitetom koji je okvir mišljenja u kojem sebstvo, umjesto da se bavi sobom kao da je čitav svijet, sebe promatra kao građanina svijeta.« (Kant, 2006, 18)

\section{Literatura}

Adorno, Theodor W. (1959), »Theorie der Halbbildung «, u: Gesammelte Schriften, Band 8: Soziologische Schriften I, str. 93-121. Dostupno na: http://www2.ibw.uni-heidelberg.de/ gerstner/adorno_halbbildung.pdf [10.3. 2011.]

Anonymous (2010), »Šta su u Prusiji napravili nakon poraza a šta mi radimo nakon pobjede?«, Aleksandar's blog, Politika.com. Dostupno na: http://pollitika. com/sta-su-u-prusiji-napravili-nakon-poraza-a-sta-mi-radimo-nakon-pobjede [17. 11. 2015.]

Athusser, Luis (2009), Ideologija i državni ideološki aparati, Beograd: Karpos.

Barber, Benjamin R. (2007), Consumed. How Markets Corrupt Children, Infantilize Adults, And Swallow Citizens Whole, New York: W. W. Norton \& Company. 
Beder, Sharon (2009), »Branded Classroom Materials«, Business-Managed Democracy. Dostupno na: http://www.herinst.org/BusinessManagedDemocracy/ education/commercialism/classroom.html [8. 5. 2014.]

Beder, Sharon; Varney, Wendy i Gosden, Richard (2009), This Little Kiddy Went to Market. The Corporate Capture of Childhood, New York: Pluto Press.

Dimić, Zoran (2013), Rađanje ideje univerziteta, Sremski Karlovci, Novi Sad: Izdavačka knjižarnica Zorana Stojanovića.

Donoghue, Frank (2008), The Last Professors: The Corporate University and the Fate of the Humanities, New York: Fordham University Press.

Engel, Michael (2000), The Struggle for Control of Public Education: Markets Ideology vs. Democratic Values, Philadelphia: Temple University Press.

Fichte, Johann Gottlieb (1956), Odabrane filozofske rasprave, Zagreb: Kultura.

Fichte, Johann Gottlieb (1995), Das System der Sittenlehre nach den Principien der Wissenschaftslehre, Hamburg: Felix Meiner Verlag.

Fichte, Johann Gottlieb (2006), Sämtliche Werke, Band VI, Berlin: Adamant Media Corporation.

Filipić, Petar (2014), Anatomija destruktivnosti. Politička ekonomija visokog školstva (u Hrvatskoj), Zagreb: Naklada Jesenski i Turk.

Hazlitt, William (1902), The Collected Works of William Hazlitt: Memoirs of Thomas Holcroft. Liber amoris. Characteristics, London: J. M. Dent \& Company.

Hedges, Chris (2011), Carstvo opsjena. Kraj pismenosti i trijumf spektakla, Zagreb: Algoritam.

Hegel, Georg Wilhelm Friedrich (2000), Fenomenologija duha, Zagreb: Naklada Ljevak.

Horkheimer, Max i Adorno, Theodor (1989), Dijalektika prosvjetiteljstva. Filozofijski fragmenti, Sarajevo: Veselin Masleša - Svjetlost.

Humboldt, Wilhelm von (1969), »Theorie der Bildung des Menschen«, u: Flitner, Andreas; Giel, Klaus (ur.), Wilhelm von Humboldt, Werke in fünf Bänden: Vol. 1 Schriften zur Anthropologie und Geschichte, Darmstad: Wissenschaftliche Buchgesellschaft, str. 234-240.

Illich, Ivan (1970), Deschooling Society, New York: Harrow Books.

Jasper, Karl (1998), Duhovna situacija vremena, Zagreb: Matica hrvatska.

Jovanović, Neven (2008), »Unbildung«, Zarez, 10, str. 47 (16. 10. 2008.). Dostupno na: http://www.zarez.hr/clanci/unbildung [12. 5. 2011.]

Kant, Immanuel (1991), »Spor fakulteta«, u: Kant, Immanuel; Schelling, Friedrich Wilhelm Joseph i Nietzsche, Friedrich, Ideja univerziteta, izabrao, preveo i predgovor napisao Branko Despot, Zagreb: Globus, str. 19-122. 
Kant, Immanuel (2000), Pravno-politički spisi, Zagreb: Politička kultura.

Kant, Immanuel (2006), Anthropology from a Pragmatic Point of View, Cambridge: Cambridge University Press.

Klein, Naomi (2002), No logo: bez prostora, bez izbora, bez posla, bez logotipa, Zagreb: V. B. Z.

Kwiek, Marek (2006), »The classical German idea of the university revisited, or on the nationalization of the modern institution«, The CPP Research Papers Series 1, Center for Public Policy Studies, Poznan, 1, str. 1-60. Dostupno na: http://www.cpp.amu.edu.pl/pdf/CPP_RPS_vol.1_Kwiek.pdf [8. 5. 2014.]

Lapp, David (1994), »Private gain, public loss«, Environmental Action, 26(1), str. 15-17.

Liessmann, Konrad Paul (2009), Teorija neobrazovanosti. Zablude društva znanja, Zagreb: Naklada Jesenski i Turk.

Lyotard, Jean-François (2005), Postmoderno stanje, Zagreb: Ibis grafika.

Molnar, Alex (2005), School Commercialism: From Democratic Ideal to Market Commodity, New York: Routledge.

Nietzsche, Friedrich (1991), »O budućnosti naših obrazovnih ustanova«, u: Kant, Immanuel; Schelling, Friedrich Wilhelm Joseph i Nietzsche, Friedrich, Ideja univerziteta, izabrao, preveo i predgovor napisao Branko Despot, Zagreb: Globus, str. 243-329.

Nietzsche, Friedrich (2003), Schopenhauer kao odgajatelj, Zagreb: Matica hrvatska.

Nietzsche, Friedrich (2012), Ljudsko, odviše ljudsko. Knjiga za slobodne duhove, Zagreb: Demetra.

Spranger, Eduard (1910), Wilhelm von Humboldt und die Reform des Bildungswesens, Berlin: Reuther und Reichard.

Vuk-Pavlović, Pavao (1996), Filozofija odgoja, Zagreb: Hrvatska sveučilišna naklada.

Vuk-Pavlović, Pavao (2007), Vrednota u svijetu, Biblioteka Sabrana djela Pavla Vuk-Pavlovića, knjiga 3, Zagreb: Hrvatsko filozofsko društvo. 


\section{HUMANISTIC EDUCATION AS THE END GOAL OF HUMAN SURVIVAL}

\section{Darija Rupčić}

The goal of this work is to emphasise the importance of the humanistic ideal of education as perceived by a pleiad of great 18th and $19^{\text {th }}$ century thinkers and philosophers. It seems that the enlightenment's founding values and its dream of the comprehensively self-educated and emancipated individual is slowly dying in our 'knowledge society'. By reducing education to training, it becomes something foreign and exterior to the human spirit. Academic communities throughout Europe and the world are experiencing a strong shift away from and renunciation of the foundational humanistic ideas of education. Much of what is propagated and proclaimed as part of the syntagm of the 'knowledge society' seems to be rhetoric. Numerous education reforms have led and lead towards the economisation and commodification of education, distorting and betraying the founding humanistic values and ideals and making the role of the critical subject nearly impossible. If the basic tasks of the university are the search for and transmission of the truth, then they are impossible if their final goal is not the education of the whole person, which are the constitutive factors humanness and humanity. Using numerous sources related to this subject, and primarily their stated ideas on education, this paper is expected to contribute to the possibility of the rediscovery and reevaluation of humanistic and enlightenment ideas of education.

Key words: education (Bildung), knowledge, idea of the university, humanistic education, neoliberal capitalism 